\title{
Effect of Indole 3-Butyric Acid and Media Type on Adventitious Root Formation in Sheanut Tree (Vitellaria paradoxa C. F. Gaertn.) Stem Cuttings
}

\author{
Daniel Brain Akakpo ${ }^{1}$, Naalamle Amissah ${ }^{1 *}$, Julius Yeboah $^{2}$, Essie Blay ${ }^{1}$ \\ ${ }^{1}$ Department of Crop Science, College of Agriculture and Consumer Sciences, University of Ghana, Accra, Ghana; ${ }^{2}$ Cocoa Research \\ Institute of Ghana (CRIG), Bole, Ghana. \\ Email: ${ }^{*}$ naalamle@gmail.com
}

Received November $18^{\text {th }}, 2013$; revised January $4^{\text {th }}, 2014$; accepted January $15^{\text {th }}, 2014$

Copyright (C) 2014 Daniel Brain Akakpo et al. This is an open access article distributed under the Creative Commons Attribution License, which permits unrestricted use, distribution, and reproduction in any medium, provided the original work is properly cited. In accordance of the Creative Commons Attribution License all Copyrights (C) 2014 are reserved for SCIRP and the owner of the intellectual property Daniel Brain Akakpo et al. All Copyright (C 2014 are guarded by law and by SCIRP as a guardian.

\begin{abstract}
Shea nuts play an important role in food security for rural folks within sub-Sahara Africa, serving as the main source of income for many people living in Northern Ghana. Unfortunately, the full economic potential of the Sheanut tree has not been fully realized due to the difficulty involved in its domestication. This difficulty in vegetatively propagating sheanut trees has greatly hindered its cultivation and the realization of its true economic potential. Two experiments were conducted to investigate the effects of rooting media and varying indole 3-butyric acid (IBA) concentrations on adventitious root formation in cuttings taken from coppiced sheanut trees. Results indicated that 3000 ppm produced significantly $(p<0.05)$ better rooting $(57.5 \%)$ than 5000 ppm (30\%), $7000 \mathrm{ppm}(45.0 \%)$ and the control (7.5\%). Although the levels of soluble sugars (SS) and total free phenols (TFP) in the cutting were significantly $(p<0.05)$ higher at the end of the experiment (after IBA treatment) compared to the start (prior to IBA treatment), the SS and TFP trends observed did not clearly explain the rooting differences found between the IBA levels investigated. Callus formation was significantly $(p<0.05)$ higher $(35.0 \%)$ in the control (no IBA). Generally, callus formation decreased with increasing IBA concentration. In the rooting media experiment, rooting was significantly $(p<0.05)$ higher in the rice husk medium $(35.0 \%)$ compared to that in the palm fiber (18.3\%), saw dust (14.1\%) and top soil (16.7\%) media.
\end{abstract}

\section{KEYWORDS}

\section{Coppiced; Indole 3-Butyric Acid; Sheanut Tree; Cuttings; Rooting Medium}

\section{Introduction}

The economic and social importance of the shea nut tree (Vitellaria paradoxa) to the local people in sub-Saharan Africa cannot be emphasized enough. The sheanut tree has gained recognition because of the heavy demand for its butter, both locally and internationally.

Shea nuts play an important role in food security for rural folks within sub-Sahara Africa. It serves as the main source of livelihood for many people living in Northern Ghana [1], especially since it becomes available during the period of food scarcity (April to July each

*Corresponding author. year). With all the social and economic importance of the sheanut tree, its nuts are still collected from the wild because sheanut trees have a long juvenile phase (period before flowering), that lasts anywhere from 10 to 25 years deterring farmers from cultivating the plant. Tree growth from seed is slow, reaching maturity after approximately 30 years [2], with an average life span of 250 years. The difficulty involved in vegetatively propagating sheanut trees has limited the cultivation of superior high-yielding and early-maturing types, and has hindered its domestication.

At present, the most reliable method for propagating $V$. paradoxa is from seed. This method of propagation is not 
without problems as sheanut seeds are recalcitrant and lose their viability shortly after harvest. Vegetative propagation has an advantage over sexual propagation in ensuring the perpetuation of true-to-type high yielding progenies and for producing uniform rootstocks for use in grafting, a technique that is gaining prominence in the West Africa sub-region.

Stem cuttings of the sheanut tree have been tried under both mist and non-mist conditions. In an experiment by Yeboah et al. [3] to investigate the rooting performance of leached sheanut cuttings in different rooting media (mixture of top soil and sand $(1: 1 \mathrm{v} / \mathrm{v})$, sand and rice husk) with or without auxin treatment, they found that rooting percentages ranged from $67.6 \%$ for cuttings rooted in rice husk and treated with Seradix (active ingredient-indole butyric acid) without leaching the cuttings to $0 \%$ in cuttings leached without treating with Seradix. Although leaching of cuttings was cited in literature to have promoted rooting of cuttings, the duration of the leaching period was found to enhance root formation [4]. In the experiment by [3] leaching for too long a period (24 hours) may have resulted in the low rooting (20\%) observed.

The objective of this study was to investigate the effect of rooting media and varying hormone concentrations on adventitious root formation in cuttings taken from coppiced sheanut trees.

\section{Materials and Methods}

Two experiments were conducted using shoots developing from coppiced mature fruit bearing sheanut trees at the Cocoa Research Institute of Ghana (CRIG)-Bole Substation in the Northern Region of Ghana from September 2009 to October 2010. The Bole substation is $9^{\circ} 01^{\prime} \mathrm{N}, 2^{\circ} 29^{\prime} \mathrm{W}, 309 \mathrm{~m}$ above sea level with an annual rainfall ranging from $600 \mathrm{~mm}$ to $1500 \mathrm{~mm}$ and mean annual minimum and maximum temperatures of $29^{\circ} \mathrm{C}$ and $31^{\circ} \mathrm{C}$ respectively.

\subsection{Effect of Indole 3-Butyric Acid Treatments on Rooting in Sheanut Stem Cuttings (Experiment 1)}

There were four (4) treatments replicated four (4) times with 20 cuttings per treatment set in a Randomized Complete Block Design (RCBD). The treatments were as follows: control (No IBA), 3000 ppm IBA, 5000 ppm IBA and 7000 ppm IBA. The different concentrations of IBA were prepared by dissolving IBA in 50\% ethanol.

\subsection{Preparation of Cuttings}

Cuttings were harvested early in the morning from 4 month-old shoots of coppiced mature shea nut trees. The cuttings used were $15 \mathrm{~cm}$ long with a girth ranging between $1.0-1.5 \mathrm{~cm}$. Each cutting had six (6) apical mature leaves. Cuttings were drenched in Dithane M 45 fungicidal solution $(2 \mathrm{~g} / 1 \mathrm{~L})$ and allowed to dry for approximately 20 - 30 minutes before being dipped in the different hormone preparations. The basal $4-5 \mathrm{~cm}$ distal portions of the cuttings were dipped for ten (10) seconds in the respective IBA concentrations. The dipped cuttings were air dried for about 10 minutes before setting in the poly-propagator. Four (4) trench polythene propagators were used. The sides of the trenches were lined with polythene sheets. The bottom $15 \mathrm{~cm}$ portion of the trenches were filled with stones followed by a $10 \mathrm{~cm}$ layer of gravel. Sterilized rice husk was used to fill the remaining depth leaving $\sim 5 \mathrm{~cm}$ at the top. The polythene sheets covering the propagators were held in place with wooden planks and with polythene bags filled with topsoil (Figure 1). The cuttings were misted with water and the poly-propagator covered immediately with polythene sheets to create a humid environment. The cuttings were watered regularly to maintain the humid environment needed for rooting.

\subsection{Effect of Rooting Media on Rooting in Sheanut Stems Cuttings (Experiment 2)}

A second experiment was conducted to determine the effect of rooting media (rice husk, top soil, saw dust and decomposed 2:1 v/v palm fibre and sand) on the rooting ability of sheanut stem cuttings. Cuttings used for this experiment were taken from 1 - 2 year-old shoots from coppiced mature trees. The cuttings were prepared and set in the same manner as in Experiment 1. There were four (4) media treatments replicated three (3) times with twenty (20) cuttings per treatment set in a randomized complete block design (RCBD). Cuttings were treated with 5000 ppm IBA dissolved in 50\% ethanol.

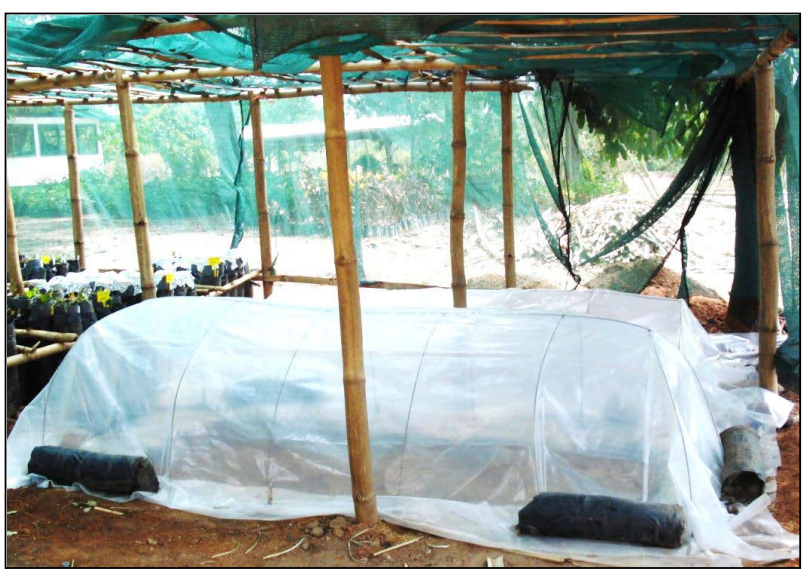

Figure 1. Polythene trench propagator used for rooting shea cuttings. 


\subsection{Environmental Conditions during Experiments 1 and 2}

Temperatures (minimum and maximum) and relative humidity of the external environment and the propagating structures were recorded daily at 9 am and 3 pm during the rooting period. It was possible to maintain about $90 \%$ to $95 \%$ humidity within the propagators by watering every other day and misting as and when needed. The propagators were opened briefly in the mornings and in the late afternoons to control temperature and to facilitate gas diffusion.

The mean maximum ambient temperature for the experimental period was $33.4^{\circ} \mathrm{C}$ and mean minimum temperature $21^{\circ} \mathrm{C}$, while the mean temperatures in the propagation structures were $37.0^{\circ} \mathrm{C}$ (maximum) and $24.4^{\circ} \mathrm{C}$ (minimum). The relative humidity (R.H) of the surrounding environment during the experimental period ranged between $84.1 \%$ in the morning ( $9 \mathrm{am}$ ) to $69.6 \%$ in the afternoon $(3 \mathrm{pm})$. The propagation structures were shaded with an overhead layer of shade net (25\% light exclusion). A portable Skye light quantum meter was used to measure photosynthetically active radiation (PAR) under the shade $\left(240.4 \mu \mathrm{mol} / \mathrm{m}^{2} / \mathrm{sec}\right)$, in the propagator $\left(180.4 \mu \mathrm{mol} / \mathrm{m}^{2} / \mathrm{sec}\right)$ and that in open environment $(820.2$ $\left.\mu \mathrm{mol} / \mathrm{m}^{2} / \mathrm{sec}\right)$.

\subsection{Determination of Carbohydrates and Phenols}

A cutting each was taken from each replicate and bulked per treatment at the start (before IBA treatment) and at the end of the rooting experiment for the analysis. The basal portions of the cuttings (approximately $6 \mathrm{~cm}$ ) were taken for biochemical analysis. The samples were analyzed according to [5] and [6] for sugars and phenols respectively.

\subsection{Data Collection and Statistical Analysis}

Cuttings from both experiments were evaluated for rooting 90 days after setting (Figure 2). A cutting was considered to have rooted if it possessed one or more roots measuring not less than $1 \mathrm{~cm}$. Data collected at the end of the rooting period were number of rooted cuttings per treatment, number of cuttings alive but without roots (dormant and callused) per treatment, number of dead cuttings per treatment, number of roots per rooted cutting and the length of the longest root (LLR) per rooted cutting. Data collected were analyzed using ANOVA in GENSTAT (Release 11.1). The Least Significant Difference (LSD) was used to determine differences among the means for the various parameters studied.
Cuttings from the control

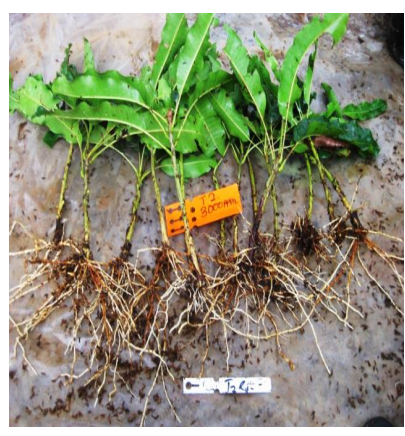

Cuttings treated with 3000 ppm IBA

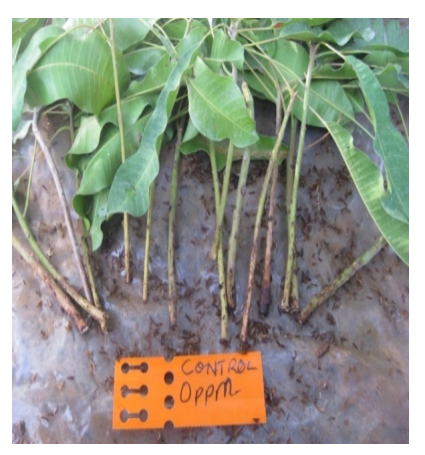

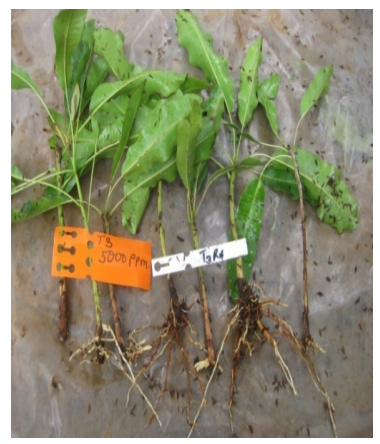

Cuttings treated with 5000 ppm IBA

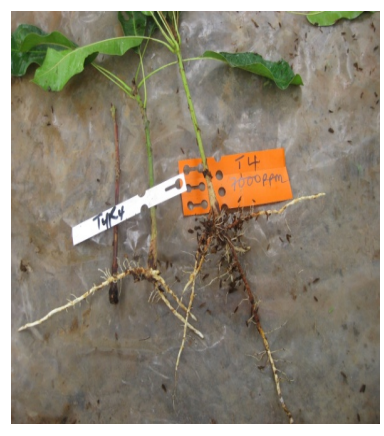

Cuttings treated with 7000 ppm IBA
Figure 2. Shea cuttings per treatment 90 days after setting.

\section{Results and Discussion}

\subsection{Effect of IBA Treatments on Rooting in Sheanut Stem Cuttings}

Cuttings treated with 3000 ppm IBA rooted best (57.5\%) with the control (no IBA) rooting the least (7.5\%) (Table 1). The percentage of dormant cuttings (alive but not rooted) at the end of the experiment was highest (46.2\%) in the control treatment which supports findings by other authors on the importance of auxin to root formation in sheanut cuttings $[3,7,8]$. Callus formation was highest (35.0\%) in the control treatment.

Generally, callus formation decreased with increasing IBA concentration (5000 ppm and $7000 \mathrm{ppm}$ ) with cuttings treated with $5000 \mathrm{ppm}$ IBA recording the highest number of dead cuttings (35.0\%) (Table 1).

The highest number of roots was recorded in cuttings treated with $5000 \mathrm{ppm}$ IBA (11 roots) and the lowest (2 roots) in the control treatment (Table 1). The different IBA concentrations investigated did not influence the length of the longest root (Table 1). Comparing the rooting trends with earlier work by [3] where talc powder preparations were used, the ethanolic quick dip method used in the present study gave better results as far as rooting percentage, root orientation, number of roots per cutting and quality of roots are concerned. 
Table 1. Effect of different IBA treatments on rooting in stem cuttings from coppiced mature sheanut trees.

\begin{tabular}{ccccccc}
\hline \multirow{2}{*}{ Treatment } & \multicolumn{7}{c}{ \% Cuttings dead/alive after 90 days } & \multirow{2}{*}{ NRPC } & LLR \\
\cline { 2 - 6 } & Rooted & Dormant & Callused & Dead & & \\
\hline Control & $7.5 \mathrm{c}$ & $46.2 \mathrm{a}$ & $35.0 \mathrm{a}$ & $11.2 \mathrm{~b}$ & $2.0 \mathrm{~b}$ & $6.9 \mathrm{a}$ \\
$3000 \mathrm{ppm}$ & $57.5 \mathrm{a}$ & $8.8 \mathrm{c}$ & $19.2 \mathrm{ab}$ & $14.5 \mathrm{~b}$ & $9.0 \mathrm{a}$ & $14.9 \mathrm{a}$ \\
$5000 \mathrm{ppm}$ & $30.0 \mathrm{~b}$ & $18.8 \mathrm{bc}$ & $16.2 \mathrm{~b}$ & $35.0 \mathrm{a}$ & $11.0 \mathrm{a}$ & $11.7 \mathrm{a}$ \\
$7000 \mathrm{ppm}$ & $45.0 \mathrm{ab}$ & $30.0 \mathrm{ab}$ & $13.8 \mathrm{~b}$ & $11.2 \mathrm{~b}$ & $6.0 \mathrm{ab}$ & $10.3 \mathrm{a}$ \\
\hline
\end{tabular}

All data represent means of four replicates. Means with different letters are significantly different at $\mathrm{p}<0.05$; NRPC: number of roots per cutting; LLR: length of the longest root per cutting.

\subsection{Comparison between Soluble, Insoluble, Total Sugars and Total Free Phenols in Sheanut Stem Cuttings}

Significant $(p<0.05)$ differences were found in the level of total free phenols (TFP), soluble sugars (SS) and total sugars (TS), in cuttings, at the beginning and end of the experiment (Table 2). SS levels were approximately five times higher at the end of experiment (Table 2). Treatments had no effect on insoluble sugars (Table 2). TFP also increased $\sim 3$-fold by the end of the experiment (Table 2).

Soluble sugars increased 5-fold at the end of the experiment. These findings confirm that photosynthesis during rooting provides carbohydrates to the base of the cutting $[9,10]$ where they promote rooting. The increase in the levels of sugars and total free phenols (TFP) at the end of the experiment may also be the result of IBA application. [10] and [11] stated that the application of rooting hormone could have an indirect influence on rooting by increasing the speed of transformation and movement of sugars and other assimilates to the base of cuttings thereby stimulating root formation. Rooting hormone application according to [4] was found to be responsible for cell division and differentiation into root primodia which finally result in roots.

This was also supported by [12] who found that carbohydrate aids in auxin transport as well as growth of the roots and increased number of roots per cutting. [13] also speculated that mobilization of carbohydrate in the leaves and upper stem to the rooting zone is influenced by hormone application. High total sugar (carbohydrates) content and TFP found in the cuttings at the end of the rooting process might also be responsible for higher rooting percentages observed in IBA treated shoots compared to the control (no IBA). However, this does not agree with findings by [14] who observed a reduction in total sugar content at the end of the rooting process by as much as $50 \%$. Rooting performances also increased as levels of total free phenols (TFP) increased during the rooting process (Tables $1 \& 2$ ). This also confirmed results by
Table 2. Soluble, insoluble, total sugars and total free phenols in stem cuttings from rejuvenated mature shea trees at the start and end of experiment.

\begin{tabular}{ccccc}
\hline \multirow{2}{*}{ Treatment } & \multicolumn{3}{c}{ Sugars (mg/g) } & $\begin{array}{c}\text { Total free } \\
\text { phenols } \\
\text { (mg/g) }\end{array}$ \\
\cline { 2 - 5 } & Soluble & Insoluble & Total & $4 \mathrm{a}$ \\
\hline Control $_{\mathrm{S}}$ & $41 \mathrm{a}$ & $32 \mathrm{a}$ & $73 \mathrm{a}$ & $28 \mathrm{~b}$ \\
Control $_{\mathrm{E}}$ & $224 \mathrm{~b}$ & $28 \mathrm{~b}$ & $252 \mathrm{~b}$ & $28 \mathrm{~b}$ \\
$\mathbf{3 0 0 0}_{\mathrm{E}}$ & $343 \mathrm{~b}$ & $19 \mathrm{~b}$ & $363 \mathrm{~b}$ & $24 \mathrm{~b}$ \\
$\mathbf{5 0 0 0}_{\mathrm{E}}$ & $416 \mathrm{~b}$ & $40 \mathrm{~b}$ & $456 \mathrm{~b}$ & $17 \mathrm{~b}$ \\
$\mathbf{7 0 0 0}_{\mathrm{E}}$ & $406 \mathrm{~b}$ & $35 \mathrm{~b}$ & $441 \mathrm{~b}$ & \\
\hline
\end{tabular}

All data represent means of four replicates. Means with different letters are significantly different at $\mathrm{p}<0.05$. Controls: analysis on cuttings taken at the start of the experiment before IBA treatment. Control $\mathrm{E}_{\mathrm{E}}, 3000_{\mathrm{E}}, 5000_{\mathrm{E}}$ and $7000_{\mathrm{E}}$ represent analysis on cuttings for the different treatments at the end of the experiment.

[15] and [14] where high rooting percentage in cuttings coincided with higher levels of phenols.

\subsection{Effect of Rooting Media on Rooting in Shea Stem Cuttings}

Significant differences in rooting were found between the various rooting media. Rice husk recorded the highest rooting percentage (35.0\%) compared to the other media [top soil (16.7\%), palm fibre (18.3\%) and saw dust (14.1\%)] (Table 3). Rice husk as a rooting medium might have enhanced the results obtained. It was indicated by [16] and [3] that rice husk enhanced rooting by creating a good aerated environment for increased respiration at the base of the cuttings.

The results confirm similar work done by [3] where rice husk gave highest rooting percentage of $36.7 \%$ as compared with $15.0 \%$ and $16.7 \%$ recorded by mixture of top soil and sand $(1: 1 \mathrm{v} / \mathrm{v})$ and sand respectively. As indicated by [17] the suitability of a medium depends on the amount and frequency of aeration. The high aeration in the rice husk medium may have created a good environment for increased respiration at the base of the cuttings and encouraged rooting as reported by [16]. The current results contradict earlier works on rooting media by $[7,18,19]$ who classified rice husk as a poor rooting medium based on its water holding capacity and rate of fungal infection. The media investigated showed no significant differences with regard to percentage callus formation, dead and dormant cuttings (Table 3 ). No significant differences $(p<0.05)$ were found between the number of roots per cutting and the length of the longest root per cutting or the different media tested. The general low rooting percentages observed in Experiment 2 compared to Experiment 1 may have been due to the differences in age of the coppiced shoots, 1 - 2 years and 4 months in Experiment 2 and 1 respectively, used. 
Table 3. Effects of type of media on rooting in sheanut stem cuttings.

\begin{tabular}{ccccccc}
\hline \multirow{2}{*}{ Treatment } & \multicolumn{9}{c}{ \% Cuttings Dead/Alive after 90 Days } & & \multirow{2}{*}{ LLR } \\
\cline { 2 - 5 } & Rooted & Dormant & Callused & Dead & & (cm) \\
\hline PF & $18.3 \mathrm{~b}$ & $35.0 \mathrm{a}$ & $15.0 \mathrm{a}$ & $31.7 \mathrm{a}$ & $5.0 \mathrm{a}$ & $4.5 \mathrm{a}$ \\
RH & $35 \mathrm{a}$ & $36.7 \mathrm{a}$ & $8.3 \mathrm{a}$ & $20 \mathrm{a}$ & $3.0 \mathrm{a}$ & $4.9 \mathrm{a}$ \\
SD & $14.1 \mathrm{~b}$ & $38.3 \mathrm{a}$ & $25 \mathrm{a}$ & $23.3 \mathrm{a}$ & $2.0 \mathrm{a}$ & $2.5 \mathrm{a}$ \\
TS & $16.7 \mathrm{~b}$ & $53.3 \mathrm{a}$ & $13.3 \mathrm{a}$ & $26.7 \mathrm{a}$ & $3.0 \mathrm{a}$ & $3.6 \mathrm{a}$ \\
\hline
\end{tabular}

All data represent means $( \pm$ S.E) of three replicates. Means with different letters are significantly different at $\mathrm{p}<0.05$. PF: palm fibre, RH: rice husk, SD: saw dust, TS: top soil.

\section{Conclusions}

The use of Indole 3-butyric promoted rooting in sheanut cuttings. Cuttings treated with 3000 ppm of IBA rooted best (57.5\%) without compromising the number of roots per cutting and the length of the longest root per cutting.

On the whole, cuttings taken from four-month old rejuvenated shoots of mature sheanut trees rooted better than those from one to two-year-old rejuvenated shoots of mature sheanut trees, suggesting the presence of a narrow window of rooting opportunity.

Although the total sugars and total free phenols increased in stem cuttings after the application of IBA, they did not significantly enhance rooting performance between the different IBA levels investigated. Rice husk turned out to be the best medium for rooting sheanut cuttings.

\section{Acknowledgements}

The authors would like to acknowledge Cocoa Research Institute of Ghana (CRIG), Bole Substation in Northern Ghana for providing plant materials and propagating structures used in this research. The authors are also grateful to the technicians at CRIG-Bole Station for their help with the research.

\section{REFERENCES}

[1] F. R. Irvine, “Woody Plants of Ghana,” Oxford University Press, London, 1961.

[2] J. M. Dalziel, "The Useful Plants of Tropical West Africa,” 3rd Edition, Crown Agencies for the Colonies, London, 1937.

[3] J. Yeboah, S. T. Lowor and F. M. Amoah, "The Rooting Performance Shea (Vitellaria paradoxa C. F. Gaertn) Cuttings Leached in Water and Application of Rooting Hormones in Different Media,” Journal of Plant Science, Vol. 4, No. 1, 2009, pp. 10-14. http://dx.doi.org/10.3923/jps.2009.10.14

[4] H. T. Hartmann, D. E. Kester, F. T. Davies Jr. and R. L. Geneve, "Plant Propagation: Principles and Practices,"
Prentice Hall, New Jersey, 2002.

[5] M. Dubois, K. A. Gilles, J. K. Hamilton, P. A. Rebers and F. Smith, "Colorimetric Methods for Determination of Sugars and Related Substances," Analytical Chemistry, Vol. 28, No. 3, 1956, pp. 350-356. http://dx.doi.org/10.1021/ac60111a017

[6] T. Swain and W. E. Hillis, "The Phenolic Constituents of Prunus domestica. I. The Quantitative Analysis of Phenolic Constituents," Journal of the Science of Food and Agriculture, Vol. 10, No. 1, 1959, pp. 63-68. http://dx.doi.org/10.1002/jsfa.2740100110

[7] K. Opoku-Ameyaw, F. M. Amoah and J. Yeboah, "Studies into Vegetative Propagation on the Sheanut Tree (Vitellaria paradoxa Gaertn)," Journal of the Ghana Science Association, Vol. 4, No. 2, 2000, pp. 138-145.

[8] J. A. Yidana, "Progress in Developing Technologies to Domesticate the Cultivation of Shea Tree (Vitellaria paradoxa L.) in Ghana," Agricultural and Food Science Journal of Ghana, Vol. 3, 2004, pp. 249-268. http://dx.doi.org/10.4314/afsjg.v3i1.37516

[9] J. Hensen, L. Stromquist and A. Ericsson, "Influence of Irradiation on Carbohydrate Content and Rooting of Cuttings of Pine Seedlings (Pinus sylvestris L.)," Plant Physiology, Vol. 81, 1978, pp. 153-159. http://dx.doi.org/10.1104/pp.61.6.975

[10] B. E. Haissig, "Carbohydrate and Amino Acid Concentration during Adventitious Roots Primodium Development in Pinus banksiana Lamb Cuttings," Forensic Science, Vol. 28, No. 4, 1982, pp. 815-821.

[11] B. E. Haissig, "Influence of Auxin and Auxin Synergist on Adventitious Root Primodium Initiation and Development,” New Zealand Journal of Forestry Science, Vol. 4, 1974, pp. 311-323.

[12] K. Wiegel, H. Horn and B. Hock, "Endogenous Auxin Levels in Terminal Stem Cuttings of Chrysanthemum morifolium during Adventitious Rooting," Physiologia Plantarum, Vol. 61, No. 3, 1984, pp. 422-428. http://dx.doi.org/10.1111/j.1399-3054.1984.tb06350.x

[13] W. Middleton, B. C. Jarvis and A. Booth, “The Role of Leaves in Auxin and Boron-Dependent Rooting of Stem Cuttings of Phaseolus aureus Roxb.," The New Phytologist, Vol. 84, No. 2, 1974, pp. 251-259. http://dx.doi.org/10.1111/j.1469-8137.1980.tb04425.x

[14] A. Henrique, E. N. Campinhos, E. O. Ono and S. Z. Pinho, "Effect of Plant Growth Regulators in the Rooting of Pinus Cuttings," Brazilian Archives of Biology and Technology, Vol. 49, No. 2, 2006, pp. 189-196. http://dx.doi.org/10.1590/S1516-89132006000300002

[15] J. Yeboah, S. T. Lowor and F. M. Amoah, "The Rooting Performance of Shea (Vitellaria paradoxa Gaertn) Stem Cuttings as Influenced by Wood Type, Sucrose and Rooting Hormone," Scientific Research and Essay, Vol. 4, No. 5, 2009, pp. 521-525.

[16] H. Evans, "Recent Investigations on the Propagation of Cacao," Imperial College of Tropical Agriculture, A Report on Cacao Research, 1945-1953, Trinidad, 1953, pp. 29-37.

[17] F. Hardy, “Cacao Manual,” Inter-American Institute of 
Agricultural Science, Turrialba, 1960, pp. 134-158.

[18] D. Adomako, J. M. Yeboah and E. B. Frimpong, "Propagation by Rooting of Cuttings, Germination and Mineral Nutrition, Analysis of Fresh Shea Fruit,” Rep. Cocoa Res. Inst., Ghana, 1985, pp. 181-182.
[19] E. Ofori-Gyamfi, "Investigation into Some Factors Affecting Vegetative Propagation of Coffee (Coffea canephora var Robusta Pierre),” Master of Philosophy Thesis, University of Cape Coast, Cape Coast, 1998, p. 173. 